\title{
THE ROLE OF RESOURCE DEPLETION IN EXPLAINING CONSEQUENCES OF PSYCHOLOGICAL CONTRACT VIOLATION
}

\author{
HONG DENG \\ Alliance Manchester Business School \\ University of Manchester \\ Booth Street West, Manchester M15 6PB UK \\ JACQUELINE COYLE-SHAPIRO \\ London School of Economics and Political Science \\ QIAN YANG \\ Zhejiang University
}

\section{INTRODUCTION}

Research on psychological contract violation has primarily relied on social exchange theory (Blau, 1964) to explain its effects on negative organizational behaviors. Revenge cognitions, the motivational intent of harmful behaviors directed at the target of revenge (Bradfield \& Aquino, 1999), is considered the underpinning of the relationship between contract violation and deviant behavior (Bordia, Restubog, \& Tang, 2008). However, the social exchange perspective is limited by its assumption that employees' responses to negative organizational treatment are always intentional, and motivated by careful calculation of gains and losses. Scholars have criticized the rationality basis of exchange and argued that instrumentality cannot exclusively and solely explain behavior (Clark \& Mills, 1979). Therefore, it is imperative to explore other theoretical accounts to examine the effects of violation (cf. Conway \& Briner, 2009). In the current research, we draw upon ego depletion theory (Baumeister, Bratslavsky, Muraven, \& Tice, 1998) and argue that psychological contract violation entails self-regulation processes and leads to resource depletion. Resource depletion, in turn, impairs the ability of self-regulation, increasing the likelihood of counter-normative behaviors and suboptimal cognitive performance (Hagger, Wood, Stiff, \& Chatzisarantis, 2010). This new perspective suggests that employees do not necessarily choose to perform poorly in response to violation. Rather, they do so because such violation drains them, rendering then unable to behave normatively. We endeavor to establish this resource-based perspective in two ways. First, we examine the mediating role of resource depletion in linking psychological contract violation to outcomes that affect third parties (i.e., interpersonal harming toward coworkers and decision-making vigilance toward clients). At the same time, we control for revenge cognitions as a traditional mediator. Second, we examine the moderating role of organizational identification because it influences regulation intensity. If the resource-based perspective is valid, organizational identification should shape the strength of this mechanism.

\section{A Resource-based Mechanism of Psychological Contract Violation}

Ego depletion theory (Baumeister et al., 1998) posits that the executive function of the self relies on finite resource capacities, which can be drained by psychological harm and frustration from stressful experiences (e.g., Christian \& Ellis, 2011; Thau \& Mitchell, 2010). Psychological contract violation is an emotional 
manifestation of a broken promise (Morrison \& Robinson, 1997), involving "feelings of betrayal and deeper psychological distress [whereby] ... the victim experiences anger, resentment, a sense of injustice and wrongful harm" (Rousseau, 1989: 129). Such experience depletes resources through three self-regulation processes. First, when employees experience the emotional distress associated with psychological contract violation, they need to suppress or neutralize their feelings to function normally and achieve organizational goals. Second, psychological contract violation may trigger effortful sense-making processes through which employees understand what has happened and why it has happened. Third, negative events such as psychological contract violation are likely to trigger rumination (Baumeister, Bratslavsky, Finkenauer, \& Vohs, 2001), and employees may attempt to cope with their ruminative thoughts. All these activities have been associated with resource depletion (e.g., Baumeister et al., 1998; Johns, Inzlicht, \& Schmader, 2008; Schmeichel, 2007).

\section{Hypothesis 1: Psychological contract violation is positively related to resource depletion.}

When individuals experience resource depletion, their ability to regulate themselves in subsequent self-control tasks is impaired (Baumeister et al., 1998). When employees are drained as a consequence of psychological contract violation, they are less capable of controlling their harmful impulses when frustrated by aversive events at work and are more likely to engage in harming behavior. Resource depletion does not necessarily affect targets that are the original source of depletion (Hagger et al., 2010). Although coworkers are not responsible for psychological contract violation, they may still become victims of depleted employees (DeWall, Baumeister, Stillman, \& Gailliot, 2007). Making decisions with vigilance is the process through which "the decision maker clarifies objectives to be achieved by the decision, canvasses an array of alternatives, searches painstakingly for relevant information, assimilates information in an unbiased manner, and evaluates alternatives carefully before making a choice" (Mann, Burnett, Radford, \& Ford, 1997: 2). Impaired self-regulatory resources have been found to lead to poor logical reasoning and cognitive extrapolation (Schmeichel, Vohs, \& Baumeister, 2003), ineffective information searching and processing (Fischer, Greitemeyer, \& Frey, 2008), suboptimal decision-making (Wan \& Agrawal, 2011), and other cognitively demanding tasks (e.g., Zyphur, Warren, Landis, \& Thoresen, 2007). Because searching and processing information are critical to decision-making vigilance (Mann et al., 1997), resource depletion may impair vigilance in decision-making.

\section{Hypothesis 2: Resource depletion is positively related to interpersonal harming toward coworkers (2a) and decision-making vigilance toward clients (2b).}

We hypothesize a positive association between psychological contract violation and resource depletion. We also hypothesize that resource depletion is positively related to interpersonal harming toward coworkers and negatively related to decision-making vigilance toward clients. Together, these suggest that resource depletion mediates the relationships between psychological contract violation and the two forms of self-regulation performance. 
Hypothesis 3: Psychological contract violation is positively and indirectly related to interpersonal harming toward coworkers (3a) and decision-making vigilance toward clients $(3 b)$ through resource depletion.

\section{The Moderating Role of Organizational Identification}

Certain factors such as psychological inconsistency or dissonance (Festinger, 1957) can make a self-regulation context particularly depleting (Thau, Aquino, \& Poortvliet, 2007). In this paper, we propose that employees' organizational identification will intensify the depleting effect of psychological contract violation by increasing the inconsistency between the actions of the organization and how employees' feel about the organization.

Organizational identification generally represents employees' positive perceptions toward their organization. However, in combination with psychological contract violation, high organizational identification provides inconsistent signals regarding one's membership and standing in the organization, resulting in cognitive dissonance (Festinger, 1957). This inconsistency or dissonance may make it more difficult for employees to make sense of such violation. Employees are also more likely to ruminate on it because they feel hurt by the organization they strongly identify with. High organizational identification thus intensifies self-regulation involved in psychological contract violation, causing more effort exertion and resource depletion. On the other hand, employees with low organizational identification do not have the sense of oneness nor think of themselves as part of their organization (Ashforth \& Mael, 1989). They may consider their organization as an "outsider" and less trustworthy. In this situation, psychological contract violation may not come as a total surprise to employees. It can even provide an account of why psychological contract violation happens. In other words, low organizational identification can serve as a psychological defense mechanism that makes the sense-making processes easier, reducing the depleting effect of psychological contract violation.

Hypothesis 4: Organizational identification positively moderates the relationship between psychological contract violation and resource depletion such that this positive relationship is stronger when organizational identification is higher rather than lower.

We hypothesize that resource depletion mediates the associations of psychological contract violation with interpersonal harming and decision-making vigilance and that organizational identification moderates the effect of psychological contract violation on resource depletion. Taken together, the above considerations constitute a first-stage moderated mediation model for psychological contract violation.

Hypothesis 5: Organizational identification moderates the indirect effects of psychological contract violation on interpersonal harming toward coworkers (5a) and decision-making vigilance toward clients (5b) through resource depletion. These indirect effects are stronger when organizational identification is higher rather than lower. 
Drawing upon previous social exchange research (Hekman, Bigley, Steensma, $\&$ Hereford, 2009), we also expect organizational identification to moderate the relationship between psychological contract violation and revenge cognitions. High organizational identification leads employees to see their organizations as relationally close to themselves (Brewer, 1979). When harm comes from an exchange partner who are relationally close, people tend to feel less vengeful and refrain themselves from the retaliating (Hornsey, Oppes, \& Svensson, 2002). In contrast, employees with low organizational identification see their organization as an outsider (Ashforth \& Mael, 1989). They tend to view harm from the organization as intentional (Beal, Ruscher, \& Schnake, 2001) and consequently feel that thoughts to retaliate are justified (Hornsey et al., 2002). This reasoning suggests that organizational identification can buffer the effect of violation on revenge cognitions. We test this possibility without forming a formal hypothesis for it.

\section{STUDY 1}

\section{METHOD}

We used the autobiographical narratives method in this study to examine the main effect of psychological contract violation on resource depletion (Baumeister, Stillwell, \& Wotman, 1990; Exline, Baumeister, Bushman, Campbell, \& Finkel, 2004). 109 full-time employees were recruited. Psychological contract violation was manipulated by having participants complete a vivid recall task. They were instructed to write an autobiographical narrative recalling a time they experienced psychological contract violation, psychological contract fulfillment, or an unrelated event. Participants were then asked to respond to a survey capturing resource depletion. The online system randomly assigned participants to one of three conditions. After completing the essay, participants were asked to complete the resource depletion survey based on how they felt during their experiences described. Two different measures of resource depletion were used in order to cross-validate the results. The first one was a 25-item state resource capacity scale from Ciarocco, Twenge, Muraven, and Tice (2007). We also used 4 items from the vitality scale developed by Ryan and Frederick (1997) to capture resource depletion. The Cronbach alpha for both measures was .97 . These two measures were also highly correlated $(r=.86, p<.01)$.

\section{RESULTS}

Results from ANOVA indicated that there was significant difference between the three experimental groups on the two resource depletion measures. With the Ciarocco et al. (2007) measure, participants in the violation condition reported significantly more resource depletion than in the fulfillment condition and the control condition. In addition, the results showed that there was significant variation between the three experimental groups on the second resource depletion (Ryan \& Frederick, 1997). Similarly, Post Hoc analysis confirmed that participants in the violation condition experienced significantly more resource depletion than in the fulfillment condition and the control condition. These findings support hypothesis 1 whereby psychological contract violation gives rise to resource depletion.

\section{STUDY 2}

\section{METHOD}


Data were collected 315 medical employees and their direct supervisors in China (response rate of 63\%). Organizational identification (Mael \& Ashforth, 1992) $(\alpha=.87)$ was measured in the first survey at Time 1 . One month later, the second survey included measures of psychological contract violation (Robinson \& Morrison, 2000) $(\alpha=.92)$ and resource depletion (Ryan \& Frederick, 1997) $(\alpha=.90)$. At Time 3 (one month after the second survey), supervisors evaluated employees iinterpersonal harming toward coworkers (Cortina, Magley, Williams, \& Langhout, 2001) $(\alpha=.72)$ and ddecision-making vigilance toward clients (Mann et al., 1997) $(\alpha=.91)$. We controlled for revenge cognitions (Bordia et al., 2008) as a mediator $(\alpha=.90)$. Random intercept models were utilized to take into account possible group effects. We estimated the conditional indirect relations using Selig and Preacher's (2008) Monte Carlo method.

\section{RESULTS}

As predicted in Hypothesis 1, psychological contract violation was positively related to resource depletion $(B=.44, p<.01)$. Also, as predicted in Hypotheses $2 \mathrm{a}$ and $2 \mathrm{~b}$, resource depletion was positively associated with interpersonal harming $(B$ $=.11, p<.05)$ and negatively related to decision-making vigilance $(B=-.15, p<.05)$, after taking into account revenge cognitions. The indirect relationship between psychological contract violation and interpersonal harming was significant and positive (estimate $=.05,95 \% \mathrm{CI}=[.01, .09])$. Similarly, the indirect association with decision-making vigilance via resource depletion was significant but negative (estimate $=-.07,95 \% \mathrm{CI}=[-.12,-.01]$ ). Thus, Hypotheses $3 \mathrm{a}$ and $3 \mathrm{~b}$ were supported. As a check, we also performed analyses for revenge cognitions. We found that there was a positive association between psychological contract violation and revenge cognitions. However, revenge cognitions was not related to interpersonal harming toward coworkers or decision-making vigilance toward clients when regressed in the same model with resource depletion.

Moreover, results demonstrated a significant and positive interaction between psychological contract violation and organizational identification on resource depletion $(B=.10, p<.05)$. We performed simple slope analysis at the value of $1 \mathrm{SD}$ above and below the mean of organizational identification (Aiken \& West, 1991). Supporting Hypothesis 4, the positive relationship between psychological contract violation and resource depletion was stronger when organizational identification was high (simple slope $=.55, p<.01$ ) than when it was low (simple slope $=.35, p<.01)$. In contrast to this enhancing moderation effect, we found there was a significant and negative interaction between psychological contract violation and organizational identification on revenge cognitions $(B=-.09, p<.05)$. The positive relationship between psychological contract violation and revenge cognitions was weaker when organizational identification was high (simple slope $=.46, p<.01)$ than when it was low (simple slope $=.64, p<.01$ ).

As expected, the conditional relationship between psychological contract violation and interpersonal harming via resource depletion was stronger when organizational identification was high (estimate $=.06,95 \% \mathrm{CI}=[.01, .12])$ than when it was low (estimate $=.04,95 \% \mathrm{CI}=[.003, .08])$. Similarly, the conditional relationship to decision-making vigilance was also stronger when organizational identification was high (estimate $=-.08,95 \% \mathrm{CI}=[-.13,-.02]$ ) than when it was low (estimate $=-.05,95 \% \mathrm{CI}=[-.10,-.01])$. Hypotheses $5 \mathrm{a}$ and $5 \mathrm{~b}$ were supported . 


\section{GENERAL DISCUSSION}

Although this research has some limitations (e.g., generalizability and causality issues), we believe it contributes to the literature in important ways. First, our research broadens the fundamental assumption underlying people's responses to psychological contract violation. The resource-based perspective points to a different account for employees' negative responses to violation. That is, psychological contract violation triggers negative behavior because it drains employees' regulatory resources, making them involuntarily behave in a counter-normative manner. Further, a tit-for-tat perspective asserts that employees direct their actions toward the focal party in response to their evaluation of social exchange relationships (Rupp \& Cropanzano, 2002). Therefore, it may not be particularly effective in explaining how the effects of psychological contract violation can transfer across contexts to influence coworkers and clients (Conway, Kiefer, Hartley, \& Briner, 2014). Our resource-based model is not limited by target specificity and thus provides a convincing framework to account for the spillover effect of violation.

Second, the investigation of the interaction effect of organizational identification contributes to our understanding of the boundary conditions of psychological contract violation. Restubog, Bordia, and Bordia (2009) found that procedural justice mitigates the detrimental effect of psychological contract breach on affective commitment. Based on this finding, one might conclude that variables that reinforce a positive exchange orientation toward organizations can cushion the harm associated with breach/violation. Our research sends a cautionary message as organizational identification, a positive evaluation of one's organization, increased the harmful impact of violation on resource depletion and consequently on the behavioral outcomes.

Finally, investigating the moderating effect of organizational identification on resource depletion also contributes to the literature on resource depletion. Scholars have examined the role of the availability of internal resources and external resources in compensating for the resource losses. Organizational identification is not directly related to one's resource repertoire, but it is found to shape the level of resource depletion associated with psychological contract violation. This examination brings new insights into understanding the dynamics involved in resource depletion processes.

\section{REFERENCES AVAILABLE FROM THE FIRST AUTHOR}




\section{REFERENCES}

Aiken, L. S., \& West, S. G. 1991. Multiple regression: Testing and interpreting interactions: Newbury Park, CA: Sage.

Ashforth, B. E., \& Mael, F. 1989. Social identity theory and the organization. Academy of Management Review, 14: 20-39.

Baumeister, R. F., Bratslavsky, E., Finkenauer, C., \& Vohs, K. D. 2001. Bad is stronger than good. Review of General Psychology, 5: 323-370.

Baumeister, R. F., Bratslavsky, E., Muraven, M., \& Tice, D. M. 1998. Ego depletion: Is the active self a limited resource? Journal of Personality and Social Psychology, 74: 1252-1265.

Baumeister, R. F., Stillwell, A., \& Wotman, S. R. 1990. Victim and perpetrator accounts of interpersonal conflict: Autobiographical narratives about anger. Journal of Personality and Social Psychology, 59: 994-1005.

Beal, D. J., Ruscher, J. B., \& Schnake, S. B. 2001. No benefit of the doubt: Intergroup bias in understanding causal explanation. British Journal of Social Psychology, 40: 531-543.

Blau, P. M. 1964. Exchange and power in social life. New York: Wiley.

Bordia, P., Restubog, S. L. D., \& Tang, R. L. 2008. When employees strike back: investigating mediating mechanisms between psychological contract breach and workplace deviance. Journal of Applied Psychology, 93: 1104-1117.

Bradfield, M., \& Aquino, K. 1999. The effects of blame attributions and offender likableness on forgiveness and revenge in the workplace. Journal of Management, 25: 607-631.

Brewer, M. B. 1979. In-group bias in the minimal intergroup situation: A cognitive-motivational analysis. Psychological Bulletin, 86: 307-324.

Christian, M. S., \& Ellis, A. P. 2011. Examining the effects of sleep deprivation on workplace deviance: A self-regulatory perspective. Academy of Management Journal, 54: 913-934.

Ciarocco, N., Twenge, J., Muraven, M., \& Tice, D. 2007. The state self-control capacity scale: Reliability, validity, and correlations with physical and psychological stress. Poster presented at the annual meeting of the Society for Personality and Social Psychology, San Diego, CA. .

Clark, M. S., \& Mills, J. 1979. Interpersonal attraction in exchange and communal relationships. Journal of Personality and Social Psychology, 37: 12-24.

Conway, N., \& Briner, R. B. 2009. Fifty years of psychological contract research: What do we know and what are the main challenges. International Review of Industrial and Organizational Psychology, 21: 71-131.

Conway, N., Kiefer, T., Hartley, J., \& Briner, R. B. 2014. Doing more with less? Employee reactions to psychological contract breach via target similarity or spillover during public sector organizational change. British Journal of Management, 25: 737-754.

Cortina, L. M., Magley, V. J., Williams, J. H., \& Langhout, R. D. 2001. Incivility in the workplace: Incidence and impact. Journal of Occupational Health Psychology, 6: 64-80.

DeWall, C. N., Baumeister, R. F., Stillman, T. F., \& Gailliot, M. T. 2007. Violence restrained: Effects of self-regulation and its depletion on aggression. Journal of 
Experimental social psychology, 43: 62-76.

Exline, J. J., Baumeister, R. F., Bushman, B. J., Campbell, W. K., \& Finkel, E. J. 2004. Too Proud to Let Go: Narcissistic Entitlement as a Barrier to Forgiveness. Journal of Personality and Social Psychology, 87: 894-912.

Festinger, L. 1957. A theory of cognitive dissonance. Palo Alto, CA: Stanford University Press.

Fischer, P., Greitemeyer, T., \& Frey, D. 2008. Self-regulation and selective exposure: The impact of depleted self-regulation resources on confirmatory information processing. Journal of Personality and Social Psychology, 94: 382-395.

Hagger, M. S., Wood, C., Stiff, C., \& Chatzisarantis, N. L. D. 2010. Ego depletion and the strength model of self-control: A meta-analysis. Psychological Bulletin, 136: 495-525.

Hekman, D. R., Bigley, G. A., Steensma, H. K., \& Hereford, J. F. 2009. Combined effects of organizational and professional identification on the reciprocity dynamic for professional employees. Academy of Management Journal, 52: 506-526.

Hornsey, M. J., Oppes, T., \& Svensson, A. 2002. "It's OK if we say it, but you can't": Responses to intergroup and intragroup criticism. European Journal of Social Psychology, 32: 293-307.

Johns, M., Inzlicht, M., \& Schmader, T. 2008. Stereotype threat and executive resource depletion: Examining the influence of emotion regulation. Journal of Experimental Psychology: General, 137: 691-705.

Mael, F., \& Ashforth, B. E. 1992. Alumni and their alma mater: A partial test of the reformulated model of organizational identification. Journal of Organizational Behavior, 13: 103-123.

Mann, L., Burnett, P., Radford, M., \& Ford, S. 1997. The Melbourne Decision Making Questionnaire: An instrument for measuring patterns for coping with decisional conflict. Journal of Behavioral Decision Making, 10: 1-19.

Morrison, E. W., \& Robinson, S. L. 1997. When employees feel betrayed: A model of how psychological contract violation develops. Academy of Management Review, 22: $226-256$.

Restubog, S., Bordia, P., \& Bordia, S. 2009. The interactive effects of procedural justice and equity sensitivity in predicting eesponses to psychological contract breach: An interactionist perspective. Journal of Business \& Psychology, 24: 165-178.

Robinson, S. L., \& Morrison, E. W. 2000. The development of psychological contract breach and violation: A longitudinal study. Journal of Organizational Behavior, 21: 525-546.

Rousseau, D. M. 1989. Psychological and implied contracts in organizations. Employee Responsibilities and Rights Journal, 2: 121-139.

Rupp, D. E., \& Cropanzano, R. 2002. The mediating effects of social exchange relationships in predicting workplace outcomes from multifoci organizational justice. Organizational Behavior and Human Decision Processes, 89: 925-946.

Ryan, R. M., \& Frederick, C. 1997. On energy, personality, and health: Subjective vitality as a dynamic reflection of well-being. Journal of Personality, 65: 529-565.

Schmeichel, B. J. 2007. Attention control, memory updating, and emotion regulation temporarily reduce the capacity for executive control. Journal of Experimental Psychology: General, 136: 241-255. 
Schmeichel, B. J., Vohs, K. D., \& Baumeister, R. F. 2003. Intellectual performance and ego depletion: Role of the self in logical reasoning and other information processing. Journal of Personality and Social Psychology, 85: 33-46.

Thau, S., Aquino, K., \& Poortvliet, P. M. 2007. Self-defeating behaviors in organizations: The relationship between thwarted belonging and interpersonal work behaviors. Journal of Applied Psychology, 92: 840-847.

Thau, S., \& Mitchell, M. S. 2010. Self-gain or self-regulation impairment? Tests of competing explanations of the supervisor abuse and employee deviance relationship through perceptions of distributive justice. Journal of Applied Psychology, 95: 1009-1031.

Wan, E. W., \& Agrawal, N. 2011. Carryover effects of self-control on decision making: A construal-level perspective. Journal of Consumer Research, 38: 199-214.

Zyphur, M. J., Warren, C. R., Landis, R. S., \& Thoresen, C. J. 2007. Self-regulation and performance in high-fidelity simulations: An extension of ego-depletion research. Human Performance, 20: 103-118. 